\title{
PHYSICAL PROPERTIES OF SEEDS OF THE SELECTED OIL PLANTS
}

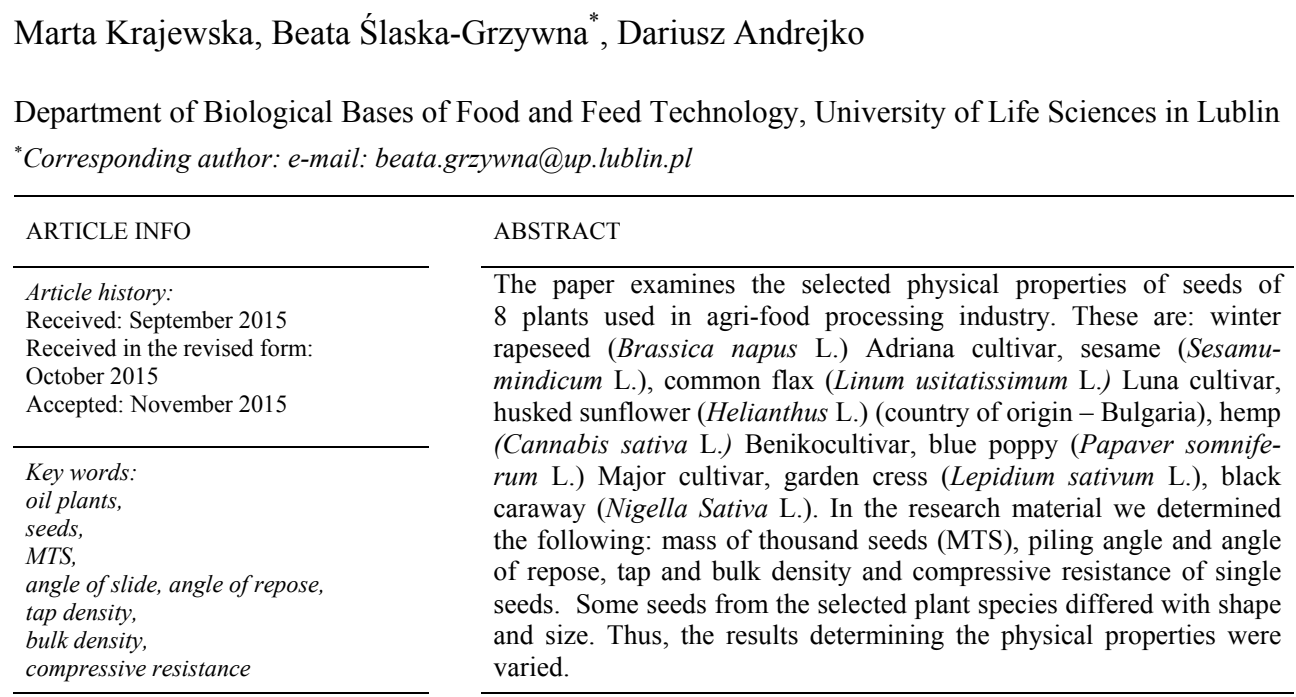

\section{Introduction}

Presently, plants rich in fat are increasingly popular in the agri-food processing industry. They are used both as a food raw material as well as a precious source of renewable energy. Scientists search for new fat raw materials with an optimal for consumers' health composition of fatty acids (Budzyński and Zając, 2010).

Plant fats are obtained in approximately $73 \%$ from one-year oil plants. They include plant species, which accumulate in their bodies at least $15-20 \%$ of fat. The obtained plant fat, after appropriate processing is used for food purposes or in various technology branches. Food fats are edible oils and raw materials for production of margarine, bakery and confectionery products. Technical use of plant fats is considerably wider. They are basic raw material for production of soap and washing agents and varnishes, lacquers and oil colours. They are used in the cosmetic industry, metallurgy and casting. In pharmacy they are used for production of ointments and liquids and in medical treatment as a component of medicaments. They are also used for impregnation and finishing of fabrics and for tanning leather. Plant fats are a component of numerous crop protection substances because they support activity of some pesticides (Jasińska and Kotecki, 1999; Kapusta, 2001, 2011, 2012).

The quality of oil plant seeds is assessed based on the general content of fat and fatty acids, the content of organic nitrogen and other organic compounds and the mineral composition of ash (Trybała, 1999). The content of fat, protein and glucosinolates in oil seeds is 
modified to the highest possible level by fertilization. High doses of nitrogen cause the increase of the protein content in seeds but they decrease their content of fat (Budzyński and Zając, 2010).

After pressing oil from seeds, cakes are obtained from the residue and after oil extraction with the use of organic solvents, the so-called meal is obtained. This residue constitutes components of rich fodder for farm animals. They are rich in protein (approximately $30 \%$ ) and fat (approx. 10\%) or raw materials for some branches of pharmaceutical and food industry (Pisulewski et al., 2001). Straw from majority of oil plants (e.g. poppy) is ligneous, hard and may contain poisonous alkoloids. Therefore, it cannot be used as fodder or bedding. In farms it is sometimes used as a base for heaps or processed into compost. It can be also used for production of paper, furniture and insulation boards and for production of furfural in chemical industry (Kapusta, 2012).

In order to determine the quality of cultivated seeds, their physical properties must be assessed. Additionally, the knowledge of those properties enable adjustment of cultivation, collection and processing technologies to fully use the crop potential of plants and to minimize the losses which may take place in these processes (Konopka et al., 2009; Szot, 2008).

The objective of the research was to examine the basic physical properties of seeds used in the food processing industry.

\section{Material and research methods}

The seeds of the following plants constituted a research material; winter rapeseed (Brassica napus L.) Adriana cultivar, sesame (Sesamumindicum L.), common flax (Linum usitatissimum L.)Luna cultivar, husked sunflower (Helianthus L.) (country of origin - Bulgaria), fibre hemp (Cannabis sativa L.) Beniko variety, blue poppy (Papaver somniferum L.)Major cultivar, garden cress (Lepidium sativum L.), black caraway (Nigella Sativa L.). The used batches of rapeseed came from a farm close to Lublin, flax and black caraway from "MIŁEX" enterprise, hemp, sesame, sunflower and poppy from F.H. AWIKO enterprise and watercress from the Seed Company in Lublin. All seeds were collected in 2014.

In order to regulate the moisture of seeds to the level of approximately $8 \pm 1 \%$, before testing they were stored in glass jars with open lids in the temperature of the surrounding $\left(20 \pm 2^{\circ} \mathrm{C}\right)$, for 14 days.

We determined the following: mass of thousand seeds (MTS), angle of slide and angle of repose, tap and bulk density and resistance to compression. Determination was carried out in three iterations. Only compressive resistance of seeds was repeated ten times. As a result, an arithmetic mean from those iterations was assumed. MTS in all tested raw materials was determined acc. to the standard PN-68/R-74017. The angle of repose was determined acc. to the standard PN-65/Z-04004.The angle of slide was determined according to the standard PN-7412-04022/08 07. The measurement of the tap density was carried out according to the methodology provided by Grochowicz and Laskowski $(1983,1987)$. The bulk density was determined according to the standard PN-ISO-7871-2:1998 07.

The compressive resistance of seeds was determined with the use of a testing machine Zwick Roell BT1-FRO.5TN.D14 with the speed of the head movement of $10 \mathrm{~mm} \cdot \mathrm{min}^{-1}$. 
Physical properties...

We carried out the resistance test of single seeds with the use of a head with the maximum strength of compression of $\mathrm{F}=500 \mathrm{~N}$.

The measurement of the compressive resistance consisted in placing single seeds (selected randomly) between the working panels of the measuring head, starting the device and registering a maximum value of power at which the sample was destroyed.

We analysed the obtained results statistically with the use of Statistica 8.0. In order to examine the significance of differences between the obtained values for particular raw materials, we carried out a one-factor analysis of variance ANOVA. We made the conclusions at the 0.05 level of significance. We carried out a detailed analysis of average confidence interval at the use of Tukey's test.

\section{Research results}

Figures 1-6 and table 1 present the basic physical properties of seeds covered by the research schedule. MTS values were varied (figure 1). The highest value of this feature for sunflower seeds was reported and it was $43.3 \mathrm{~g}$. Slightly lower value was characteristic for hemp seeds $(21.2 \mathrm{~g})$ and for the remaining seeds the reported value was within $0.5 \mathrm{~g}$ for poppy seeds to $6.6 \mathrm{~g}$ for flax seeds. Such variety of MTS values resulted mainly from varied sizes of seeds and their chemical composition. The obtained values do not differ from the values provided by other Authors e.g. b y Budzyński and Zając (2010).

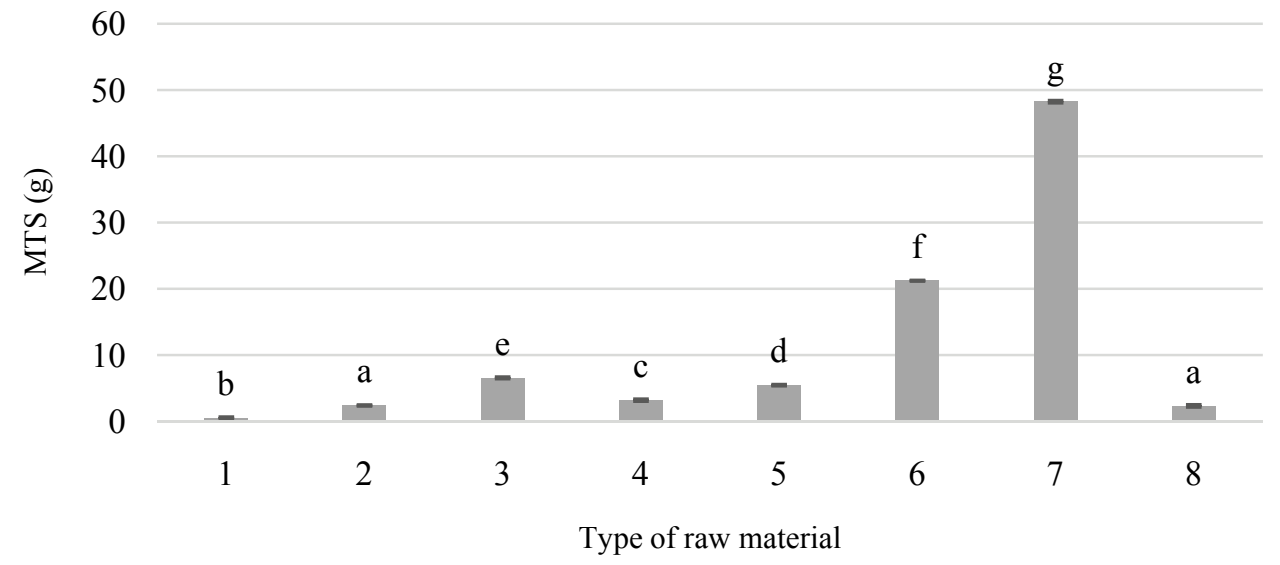

Figure 1. MTS of: 1 - poppy, 2 - sesame, 3 -flax, 4 - nigella, 5 - rapeseed, 6 - hemp, 7 - sunflower, 8 - watercress (various letters over the column stand for statistically significant differences)

Flowability, also known as movability is one of the properties which determine the surface properties of seeds. At the free flow of seeds on the horizontal plane, a cone with a natural slope is formed. Its angle of deviation is called the angle of natural slope or angle 
of slide. The size of this angle depends mainly on the size of seeds, their construction, shape, moisture and presence of contaminations. Dry, round or almost round seeds with a flat surface have the highest flowability (Konopka et al., 2013).

The obtained values of the angle of slide (figure 2) were within $30.3^{\circ}$ for the watercresss seed to $50^{\circ}$ for hemp seeds and $50.3^{\circ}$ for rape seeds.

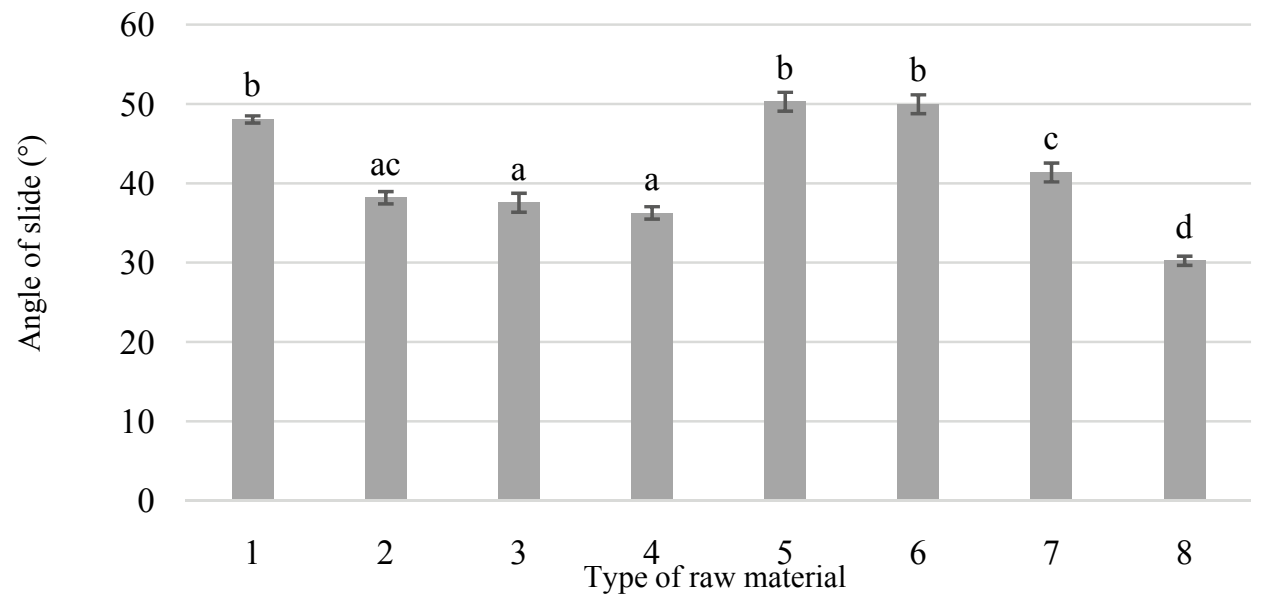

Figure 2. Angle of slide of seeds: 1 - poppy, 2 - sesame, 3 -flax, 4 - nigella, 5 -rapeseed, 6 - hemp, 7 - sunflower, 8 - watercress (various letters over the column stand for statistically significant differences)

Angle of repose is the next measure of the seeds flowability degree. It is the smallest angle of deviation of the surface at which the slide of the loose material takes place. The angle of repose is usually a few degrees lower than the angle of slide (Konopka et al., 2013). Values of the angle of repose of seeds covered by the research schedule (figure 3 ) were varied and were at the level from $15.3^{\circ}$ for hemp seeds to $31.1^{\circ}$ for the sesame seeds.

The coefficient of external friction, which may be more easily estimated through calculation of the tangent of the angle of repose, is a vital physical property strictly related to the angle of repose. The obtained values were presented in table 1. Analogically as in case of the measurement of the angle of repose the lowest values were reported for the hemp seeds $(0.2742)$ and the highest for the sesame seeds $(0.6080)$.

Figure 4 presents the results of the measurement of the tap density of the researched raw material. Watercress and poppy seeds had the highest tap density which was respectively $750.1 \mathrm{~g} \cdot \mathrm{dm}^{-3}$ and $726.8 \mathrm{~g} \cdot \mathrm{dm}^{-3}$, the lowest value of this property was reported for sunflower seeds $\left(589.5 \mathrm{~g} \cdot \mathrm{dm}^{-3}\right)$. Results for the remaining seeds covered by the research schedule were within $615.8 \mathrm{~g} \cdot \mathrm{dm}^{-3}$ for hemp seeds to $702.6 \mathrm{~g} \cdot \mathrm{dm}^{-3}$ for flax seeds.

Research results concerning the bulk density were presented in figure 5. Bulk density depends on the shape of single particles of the shaken material as well as on the distribution of seeds after shaking. The more compacted and shaken the seeds are, the higher is the bulk density. 
Physical properties...

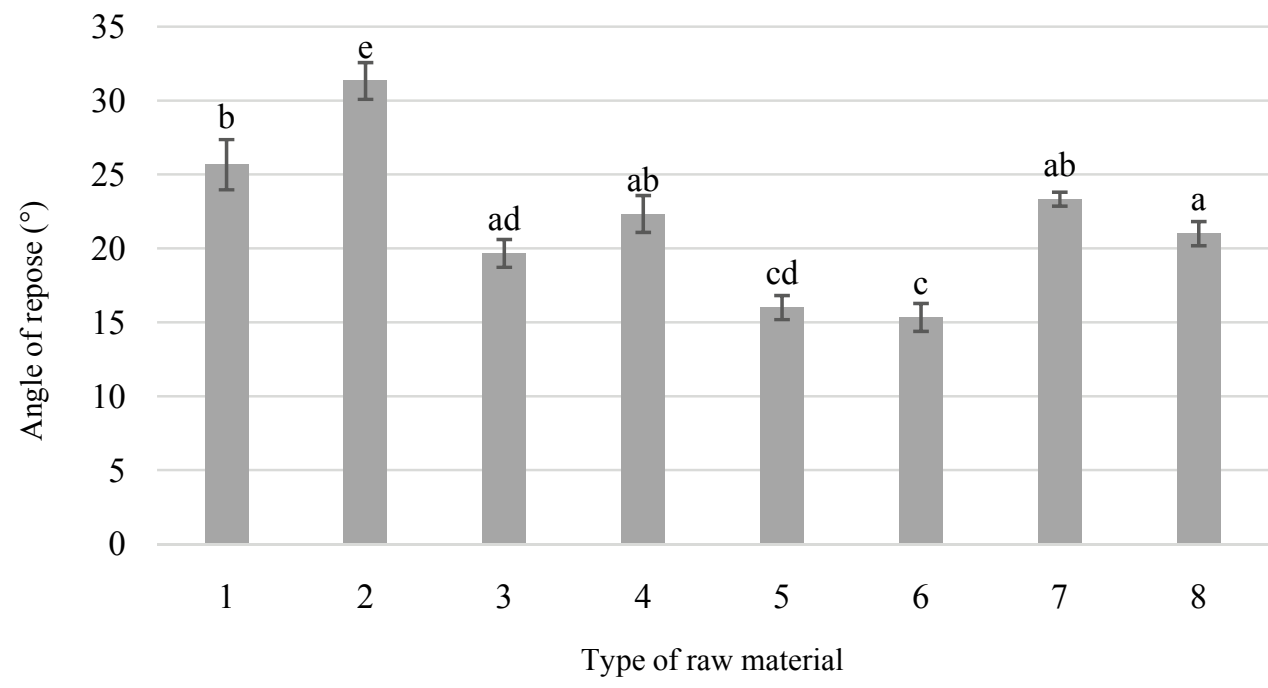

Figure 3. Angle of repose of seeds: 1 - poppy, 2 - sesame, 3 - flax, 4 - nigella, 5 - rapeseed, 6 - hemp, 7 - sunflower, 8 -watercress (various letters over the column stand for statistically significant differences)

Table 1.

The values of the coefficient of external static friction of the examined seeds

\begin{tabular}{lcc}
\hline $\begin{array}{l}\text { Raw } \\
\text { material }\end{array}$ & $\begin{array}{c}\text { Raw material } \\
\left({ }^{\circ}\right)\end{array}$ & $\begin{array}{c}\text { Coefficient } \\
\text { of external friction }\end{array}$ \\
\hline Poppy & 25.7 & 0.4806 \\
Sesame & 31.3 & 0.6080 \\
Flax & 19.7 & 0.3574 \\
Black caraway & 22.3 & 0.4108 \\
Rapeseed & 16.0 & 0.2867 \\
Hemp & 15.3 & 0.2742 \\
Sunflower & 23.3 & 0.4314 \\
Watercress & 21.0 & 0.3839 \\
\hline
\end{tabular}


Marta Krajewska, Beata Ślaska-Grzywna, Dariusz Andrejko

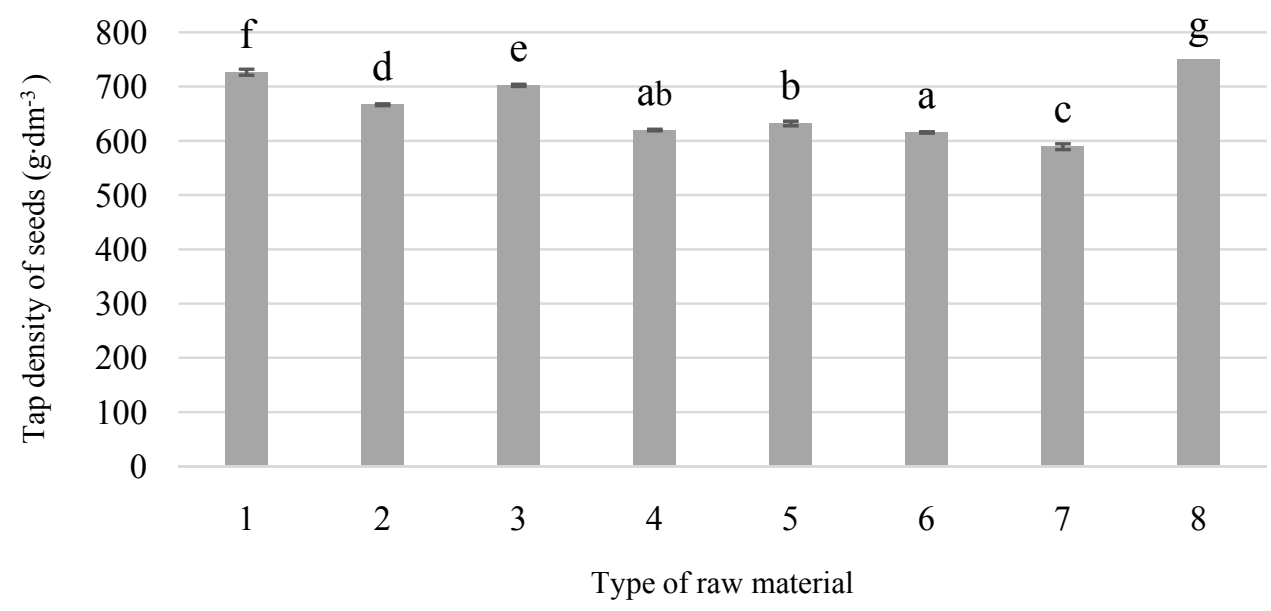

Figure 4. Tap density of seeds: 1 - poppy, 2 - sesame, 3 -flax, 4 - nigella, 5 - rapeseed, 6 - hemp, 7 - sunflower, 8 - watercress (various letters over the column stand for statistically significant differences)

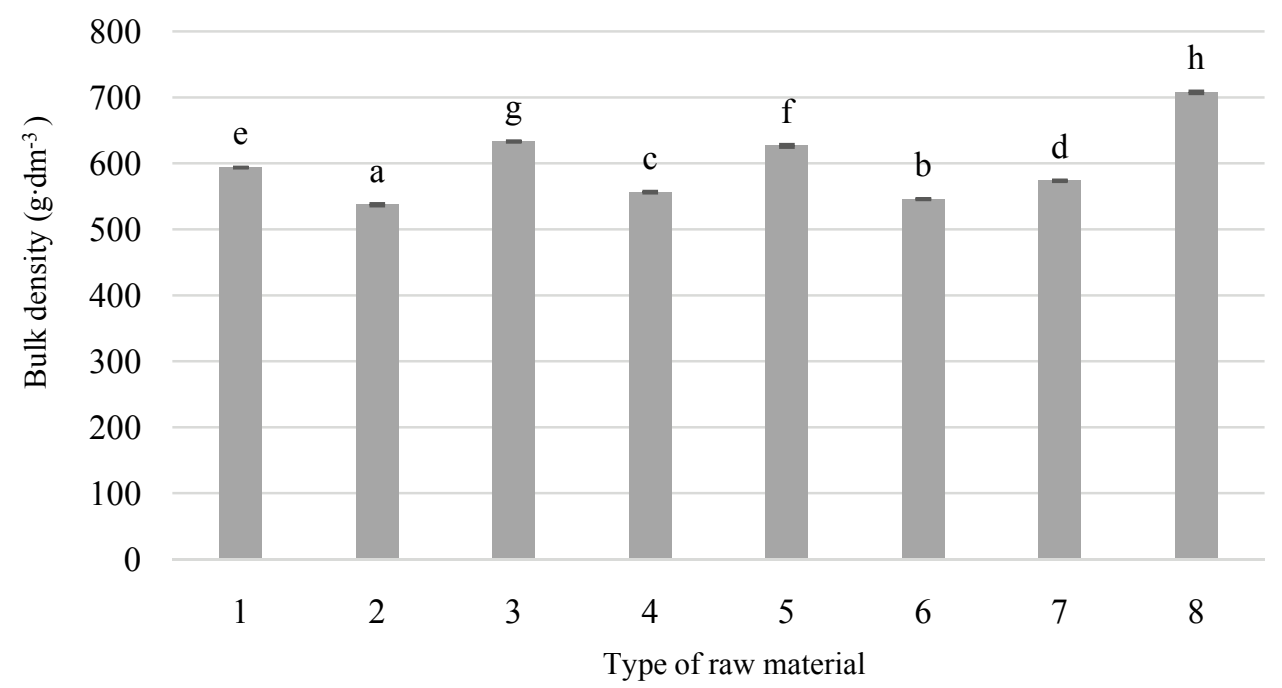

Figure 5. Bulk density of seeds: 1 - poppy, 2 - sesame, 3 -flax, 4 - nigella, 5 - rapeseed, 6 - hemp, 7 - sunflower, 8 -watercress (various letters over the column stand for statistically significant differences) 
Physical properties...

The research proved that the watercress seeds had the highest bulk density $\left(707.8 \mathrm{~g} \cdot \mathrm{dm}^{-3}\right)$. The remaining values were at the level of $537.5 \mathrm{~g} \cdot \mathrm{dm}^{-3}$ (sesame seeds) to $633.3 \mathrm{~g} \cdot \mathrm{dm}^{-3}$ (flax seeds).

The results of the seeds compression resistance measurement presented in figure 6 proved significant diversity. The biggest compressing force was necessary to destroy the sunflower seeds $(124.1 \mathrm{~N})$. Values of the compression force for the remaining seeds were considerably lower and were within $2.6 \mathrm{~N}$ for the poppy seeds to $37.1 \mathrm{~N}$ for hemp seeds. The reported differences of the measured force result mainly from a considerable diversity of dimensions and a shape of seeds, anatomic structure and chemical composition, including the fat and water content (Stępniewski et al., 2003; Szot, 2008).

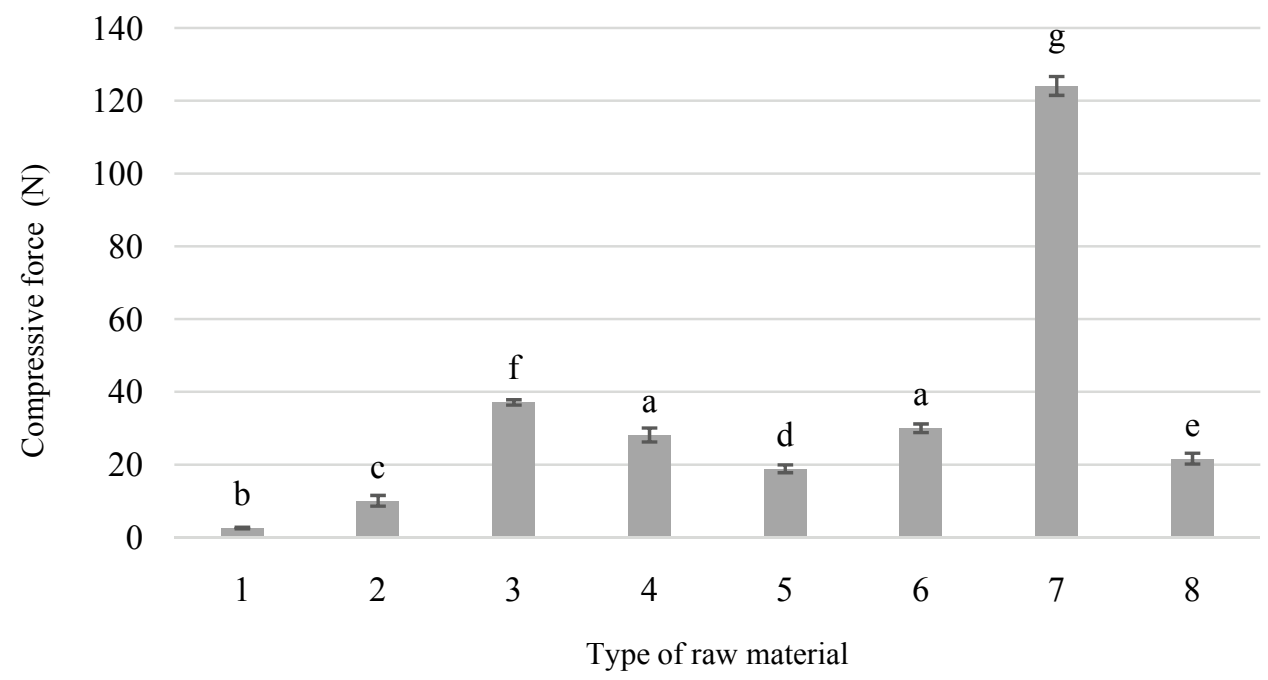

Figure 6. Compressive force of seeds 1 - poppy, 2 - sesame, 3 - flax, 4 - nigella, 5 - rapeseed, 6 - hemp, 7 - sunflower, 8 -watercress (various letters over the column stand for statistically significant differences)

\section{Conclusions}

1. Poppy, sesame, flax, nigella, rapeseed and watercress seeds have similar MTS values at the level from $0.5 \mathrm{~g}$ for poppy seeds to $6.6 \mathrm{~g}$ for hemp seeds. Hemp and sunflower seeds have considerably higher values of this property which are respectively $21.2 \mathrm{~g}$ and $48.3 \mathrm{~g}$.

2. The biggest angle of slide is characteristic for rape seeds $\left(50.3^{\circ}\right)$ and hemp seeds $\left(50.0^{\circ}\right)$ resembling a ball and the watercress seeds have the lowest angle of slide which is $30.3^{\circ}$.

3. The angle of repose for the tested raw materials is lower in comparison to the angle of slide. Sesame seeds have the highest value $\left(31.3^{\circ}\right)$ and hemp seeds - the lowest $\left(15.3^{\circ}\right)$. 
4. Coefficient of external static friction of seeds covered by research is within 0.2742 for hemp seeds to 0.6080 for sesame seeds.

5. Sesame, flax, nigella, rapeseed, hemp and sunflower seeds have a similar value of the tap density within $589.5 \mathrm{~g} \cdot \mathrm{dm}^{-3}$ for sunflower seeds to $666.9 \mathrm{~g} \cdot \mathrm{dm}^{-3}$ for sesame seeds. The poppy seeds $\left(726.8 \mathrm{~g} \cdot \mathrm{dm}^{-3}\right)$ and watercress seeds $\left(750.1 \mathrm{~g} \cdot \mathrm{dm}^{-3}\right)$ have considerably higher values of tap density.

6. The highest density in the bulk state is characteristic for watercress seeds $(707.8 \mathrm{~g} \cdot \mathrm{dm}-$ ${ }^{3}$ ), and the values of this property for other seeds are from $537.5 \mathrm{~g} \cdot \mathrm{dm}^{-3}$ (sesame seeds) to $633.3 \mathrm{~g} \cdot \mathrm{dm}^{-3}$ (flax seeds).

7. The biggest compressing force is necessary to destroy the sunflower seeds structure $(124.1 \mathrm{~N})$. Values of the compression force for the remaining seeds are considerably lower and are within $2.6 \mathrm{~N}$ for the poppy seeds to $37.1 \mathrm{~N}$ for flax seeds.

\section{References}

Budzyński, W., Zając, T. (Red.). (2010). Rośliny oleiste uprawa i zastosowanie. Praca zbiorowa. PWRiL, Poznań. ISBN 978-83-09-99033-8.

Grochowicz, J., Laskowski, J. (1983). Analiza metod określania fizycznych właściwości surowców i mieszanek paszowych. Biuletyn Informacyjny Przemystu Paszowego, 3-4, 1-12.

Grochowicz, J., Laskowski, J. (1987). Metody oznaczania fizycznych właściwości surowców i mieszanek paszowych. Zeszyty Problemowe Postępów Nauk Rolniczych, 321, 83-90.

Jasińska, Z., Kotecki, A. (red.) (1999). Szczegółowa uprawa roślin. Praca zbiorowa. Tom II, Wydawnictwo Akademii Rolniczej we Wrocławiu. ISBN 8387866164

Kapusta, F. (2001). Przemiany bazy surowcowej przemysłu olejarskiego w Polsce. Prace Naukowe Uniwersytetu Ekonomicznego we Wrocławiu, 917, Technologia 8, 33-40.

Kapusta, F. (2011). Produkcja roślin oleistych i ich przetwórstwo w Polsce. Prace Naukowe Uniwersytetu Ekonomicznego we Wroctawiu, 204, Nauki Inżynierskie i Technologie, 3, 120-123.

Kapusta, F. (2012). Znaczenie roślin oleistych dla człowieka, rolnictwa i kraju. Wieś Jutra, 5-6, 166167.

Konopka, S., Jeliński, T., Sadowska, J., Błaszczak, W., Fornal, J., Rybiński. (2009). Podstawowe właściwości fizyczne nasion lędźwianu siewnego (Lathyrussativus L.). Acta Agrophysica, 14(1), 95-108.

Konopka, I., Tańska, M., Faron, A. (2013). Towaroznawstwo i przechowalnictwo zbóż i nasion oleistych. Przewodnik do zajęć laboratoryjnych. Uniwersytet Warmińsko-Mazurski w Olsztynie, Katedra Przetwórstwa i Chemii Surowców Roślinnych, Wydział Nauki o Żywności. ISBN 01303-15-C.

Pisulewski, P. M., Kowalski, Z. M., Szymczyk, B. A. (2001). Żywieniowe metody modyfikowania składu i kształtowanie właściwości funkcjonalnych produktów pochodzenia zwierzęcego (mleko, mięso, jaja). Postepy Nauk Rolniczych, 2, 59-72.

Stępniewski, A., Szot, B., Sosnowski, S. (2003). Uszkodzenia nasion rzepaku w pozbiorowym procesie obróbki. Acta Agrophysica, 2(1), 195-203.

Szot, B. (2008). Ocena podstawowych właściwości fizycznych nasion rzepaku jarego. Acta Agrophysica, 12(1), 191-205.

Trybała, M. (1999). Produkcja i przechowywanie płodów rolniczych. Wydawnictwo Akademii Rolniczej we Wrocławiu. ISBN 8387866563. 
Physical properties...

\section{WLAŚCIWOŚCI FIZYCZNE NASION WYBRANYCH ROŚLIN OLEISTYCH}

Streszczenie. W pracy zbadano wybrane właściwości fizyczne nasion 8 roślin wykorzystywanych w przetwórstwie rolno-spożywczym, takich jak: rzepak ozimy (Brassica napus L.) odmiany Adriana, sezam indyjski (Sesamum indicum L.), len zwyczajny (Linum usitatissimum L.) odmiany Luna, słonecznik łuskany (Helianthus L.) (kraj pochodzenia - Bułgaria), konopie siewne (Cannabis sativa L.) odmiany Beniko, mak niebieski (Papaver somniferum L.) odmiany Major, rzeżucha ogrodowa (Lepidium sativum L.), czarnuszka siewna (Nigella Sativa L.). W materiale badawczym oznaczono: masę 1000 nasion (MTS), kąt zsypu i usypu nasion, gęstość utrzęsioną i usypową nasion oraz wytrzymałość pojedynczych nasion na ściskanie. Niektóre nasiona spośród wybranych gatunków roślin różniły się między sobą zarówno kształtem jak i wielkością, stąd też wyniki oznaczeń właściwości fizycznych były zróżnicowane.

Słowa kluczowe: rośliny oleiste, nasiona, MTS, kąt usypu, kąt zsypu, gęstość utrzęsiona, gęstość usypowa, wytrzymałość na ściskanie 